\title{
Correction: Evaluation of spine MRIs in athletes participating in the Rio de Janeiro 2016 Summer Olympic Games
}

Michael S Wasserman, Ali Guermazi, Mohamed Jarraya, et al. Evaluation of spine MRIs in athletes participating in the Rio de Janeiro 2016 Summer Olympic Games. BMJ Open Sport Eं Exercise Medicine 2018;4:e000335. DOI: 10.1136/bmjsem-2017-000335.

The fifth author's surname was incorrectly spelt, it is Abdalkader (not AbdelKader).

Open Access This is an Open Access article distributed in accordance with the Creative Commons Attribution Non Commercial (CC BY-NC 4.0) license, which permits others to distribute, remix, adapt, build upon this work non-commercially, and license their derivative works on different terms, provided the original work is properly cited and the use is non-commercial. See: http://creativecommons.org/licenses/by-nc/4.0/

(c) Article author(s) (or their employer(s) unless otherwise stated in the text of the article) 2018. All rights reserved. No commercial use is permitted unless otherwise expressly granted.

BMJ Open Sport Exerc Med 2018;4:e000335corr1. doi:10.1136/bmjsem-2017-000335corr1

A) Check for updates 